\title{
Technical Skills Evaluation Based on Competency Model for Human Resources Development in Technical and Vocational Education
}

\author{
Kahirol Mohd Salleh ${ }^{1} \&$ Nor Lisa Sulaiman ${ }^{1}$ \\ ${ }^{1}$ Faculty of Technical and Vocational Education, Universiti Tun Hussein Onn Malaysia, Malaysia \\ Correspondence: Kahirol Mohd Salleh, Faculty of Technical and Vocational Education, Universiti Tun Hussein \\ Onn Malaysia, Malaysia. E-mail: kahirol@uthm.edu.my
}

Received: February 1, 2015 Accepted: May 16, 2015 Online Published: June 13, 2015

doi:10.5539/ass.v11n16p74 URL: http://dx.doi.org/10.5539/ass.v11n16p74

\begin{abstract}
The purpose of this paper is to advance discussion of the function of the competency model for the technical skills evaluation and preparation of human resource and workers in organization. Human resources development is one of the important elements that determine the status of a country, whether it is recognized as a developed, developing or underdeveloped country. To realize it vision to be a developed country by the year 2020, Malaysia had planned, carried out and developed its human resources through Technical and Vocational Education (TVE). The competency-based education, which has been introduced in TVE, is a new approach in producing not only quality and expert human resources but also technical workers that possess high competency in behavioral and thinking with regard to technical tasks. A few competency models can be applied as evaluation and assessment system in order to evaluate the technical competency of human resources. Model for Human Resource Development (HRD) Practice is proposed to determine the evaluation and assessment system that can gauge worker competency in carrying out tasks related to technical skills.
\end{abstract}

Keywords: competency model, human resource development, technical and vocational education

\section{Introduction}

Economic growth and sustainable development in all countries is being influenced by high knowledge and skills. In order to maintain and improve healthy competition especially among industries, knowledgeable and skilled manpower is the key factor that contributes to the success of any developed country. Thus, skilled workforce, through the Technical and Vocational Education (TVE) is one of the methods in providing technical-based work force in the future job market and achieving sustainable nation (Ayonmike, Okwelle, \& Okeke, 2014).

TVE is a discipline of education that provides capable and competence human resources with technical and vocational expertise in the job market. Preparation programmed such as the Tech Prep and contextual learning, which are provided in the technical and vocational education have effectively and dynamically trained human resources in this technology driven world. TVE was designed and structured specifically to provide technical preparation in specified fields and build student competency. Ruhland, Jurgens, and Ballard (2003) argued that technical preparation in TVE was designed to provide a program for career preparation and workforce development. Similarly, Alseddiqi, Mishra, and Pislaru (2012) remarked that TVE system is to equip the students with skills, knowledge, and work ethic required for various industries. It is also prepare the students for the workforce.

According to Sulaiman (2012), TVE contributes towards workforce preparation and helps in making Malaysia an industrialized country as compare to other developed countries. TVE is also capable of producing human resources who are skilled in carrying out technical-oriented task. Her views are similar by Bello, Shu'aibu, Saud, and Buntat (2013) who maintained that TVE, together with human resource development are the key contributors to the technical manpower in Malaysia. Thus, TVE plays a very important role in generating knowledgeable and skilled workers of world standard to realize Malaysia's dream to achieve a developed nation status by the year 2020. Report from The Third Outline Perspective Plan 2001-2010, Economy Planning Unit, Ministry (EPU), Prime Minister's Department, stated that 227,900 professional and technical workers are needed in the industrial sector in Malaysia. Higher institutions and training centers are two main sources of manpower that help to make up for this figure (Malaysia Government, 2001). 
The education system in Malaysia needs to be improved so as to prepare for human resources who are not only multiple-skilled but also knowledgeable and with lifelong learning readiness. Sauber, McSurely, and Tummala (2008) indicate that educational programs are becoming outcome-oriented and curricula are being designed based on competencies. The human resources also need to acquire and apply knowledge, theories and practices especially in the present state of advanced technology (Malaysia Government, 2001). Nevertheless, some issues arise with regard to performing duties at the workplace pertaining this competitive and competent human resource development. One of them is the form of evaluation to assess the level of competency of the human resources with TVE background.

The form of evaluation for the human resources needs to be examined explicitly since it is the most important factor in determining the quality of the workers. Rumler model, as illustrated in Figure 1, shows a specific situational model of individual performance at the workplace. In this model, an individual needs to provide feedbacks or to form actions regarding the work situation. The feedbacks or actions are formed by the work output from the individual whereby all information gathered from the work output will be directed back to the individual and will be interpreted either as a positive, a negative or a neutral effect. Daugherty, Teng, and Cornachione (2007) argued that the feedback should be beneficial to the human resource, which is facing the demands and needing innovative, efficient and high quality approached and solutions.

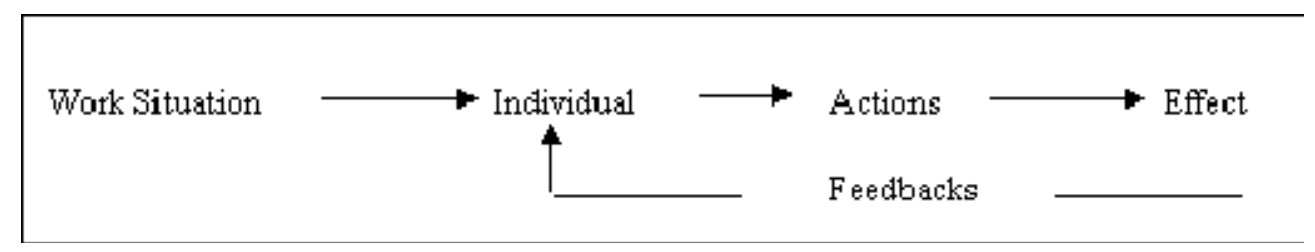

Figure 1. Rumler model (Rothwell \& Kazanaz, 1992; in Hoffmann, 1999)

The model proposed that the performance and quality of the human resources are determined by the feedbacks from the effects that exist in the work situation. Figure 2 gives illustration on how to enhance the performance of the human resources in carrying out certain task via comprehension, knowledge and the basis of individual purpose of job competency. It shows that there is a significant relationship between the performance and competency of the human resources in carrying out technical-related tasks. Hoffmann (1999) argued that relationship between performance and competency can be used as tools to distinguish between competencybased learning programs for training programs and a search for competencies to inform the content of education and development programs. Additionally, June, Kheng, and Mahmood (2013) indicate that competency-based assessment allows organizations to know the level of job performance among employees and eventually improve on job performance.

\begin{tabular}{llll}
\hline & Individual & Organization & Purpose \\
\hline Output & Performance Standards & Benchmarks & Performance based objectives (Training) \\
Inputs & Knowledge, Skills and Abilities & Inner strength & Subject matter content (Education) \\
\hline
\end{tabular}

Figure 2. Relationship between performance and competency (Hoffmann, 1999)

\section{Proposal for the Evaluation of Human Resource in TVE}

Knowledge in the evaluation aspect on the level of competency of the human resources will help organizational managers to prepare for more competitive job market by practicing strategic planning and effective administration. Serpell and Ferrada (2007) remarked that good human resources management function should be aligned with the strategy of the organization, and effectively achieved through the application of the competency approach. The main purpose of developing the human resources through the TVE is to enhance their potential and talent in technical skills in order to secure more competitive job market value in the future. By applying TVE approach, the competency model is one of the references that can evaluate the competency of the human resources and workers.

Competency-based Education is a measuring tool for technical and vocational education that is implemented in a formal education system. Its purpose is to enable easier assessment on the relevancy of a certain programmed that is implemented in schools, higher institutions or training centers. Figure 3 illustrates on how students' 
performance is evaluated through assessment on the competence characteristics. In competency-based education, students have to master the skills, ability and knowledge in the learning process.

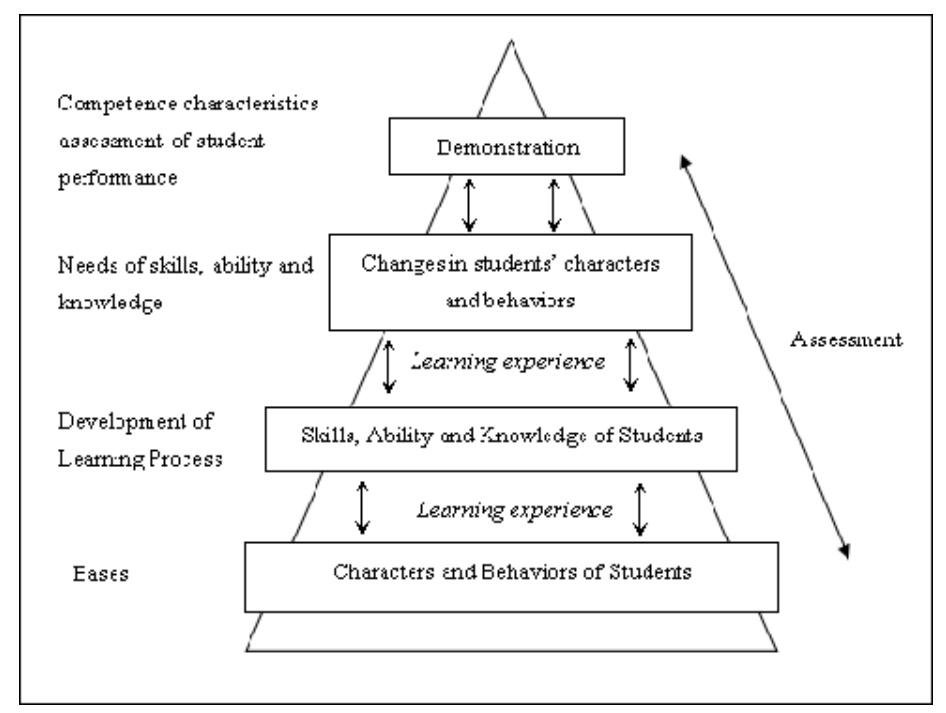

Figure 3. Achievements and ability hierarchy of students (Jones, Voorhees, \& Paulson, 2002)

\section{Competency-based Education}

Ashworth and Saxton (1990) proposed that competence means descriptive aspects of activities done by human, but does not refer to specific behaviors. These activities include contribution or results from actions taken in fulfilling behavior or thought. Activities done at the workplace by the human resource practitioners and workers are often measured by the work-based competency on behavior or thought in performing the tasks given. The process of developing workers competency in term of knowledge, skills, and attitude are referring to learning process. Salleh, Sulaiman, and Gleockner (2015) remarked learning process plays an important role in any organization.

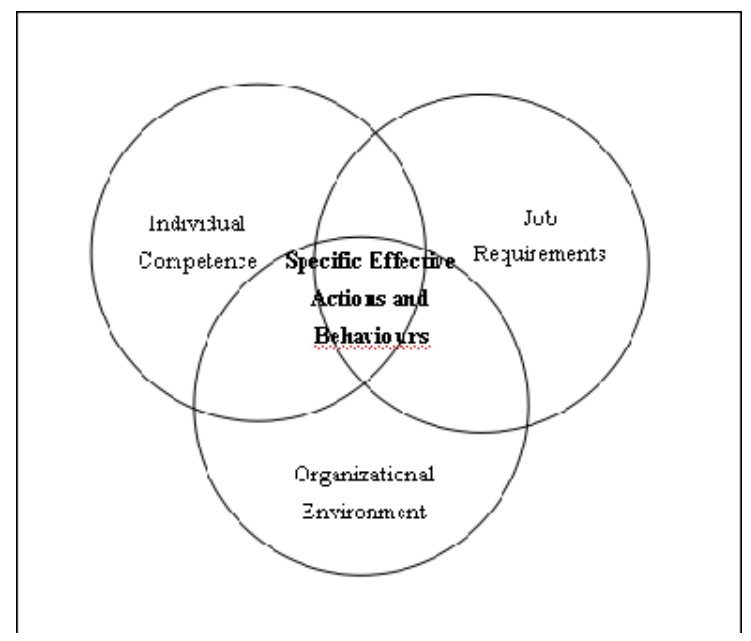

Figure 4. Effective job performance model (Boyatzis, 1982)

Salleh (2012) remarks that competency refers to the individual or worker's performance as related to organization performance in doing tasks or jobs that can be evaluated or measured. Competency can also be used as a benchmark or a measurement tool to ensure quality job output. However, competency needs to be considered as a form that represents the overall performance of the organization and not only focuses on individual due to the strong relationship that exists between the performance of the whole organization and the performance of individual. Homer (2001) stated that competency is the highest level for an organization because of the chain-effect that exists which involves processes, profits, time, and training. Therefore, Competency-based 
Education can be used as a benchmark to identify and evaluate the work effectiveness and also functions as an improvement in education and training to fulfill the needs of the workplace (Kerka, 1998). Competency-based education is an approach that combines excellent and creative ideas that can be implemented in the work environment. It is also a symbol of recognition for the education received by the technical human resources. Figure 4 illustrates the relationship between competency needs of workers and organizational environment and also job requirements. Positive effects can be seen when all the three aspects related to more positive behaviors are being fulfilled.

\section{Evaluation of Technical Skills Using the Competency Model}

There are few competency models that can be used as references or benchmarks in evaluating worker performance in carrying out task through the technical and vocational education approach. One of them is a competency model which has been adapted and modified from Model for HRD Practice (McLagan, 1989). Dubois (1993) defined competency model as those competencies that are required for satisfactory or exemplary job performance within the context of a person's job roles, responsibilities and relationship in an organization and its internal and external environment. Model for HRD Practice is a reference to facilitate evaluation on individuals and organizations (McLagan, 1996). The basic principle of this competency model is that individual performance will improve if he or she possesses all the competence characteristics that are needed to perform the task or responsibility given.

Competence characteristics in the evaluation model refer to knowledge, skills and behaviors that are needed for individual to perform a certain task or responsibility. The effectiveness of McLagan model was proven by previous researchers (Holton \& Trott, 1996), who studied the level of competency among students attending Technical and Vocational Education in Louisiana State University, United States.

McLagan Competency Model is divided into four main levels including (1) Technical Competency, (2) Business Competency, (3) Interpersonal Competency, and (4) Intellectual Competency. Seven out of ten sub-competencies that involve Technical Competency will be explained explicitly as proposal elements in this paper.

\section{Technical Competency}

\subsection{Adult Learning Comprehension}

This competency tests the comprehension of adult students and identifies their level of needs and usage of skills, knowledge, and attitude in the learning process. It is also related to the teachers or leaders' comprehension of the methods in understanding how adult students learn differently from one another. Adult learning is more of a self-directed learning. Hence, evaluation should not only be ongoing but also taken into account their experience.

\subsection{Comprehension Techniques and Career Building Theory}

Knowledge is something that is related to career building. It also stresses on the comprehension aspect of an individual in shaping career in the future. Overall, it is a combination of ability, comprehension technique and methods used in a career development.

\subsection{Skills in Identifying Competency}

Identifying knowledge and skills required to carry out certain job, task and knowing the real function of the individual post in the organization. It involves tasks and instructions received from the employer. The ability of an employee in carrying out certain tasks is greatly influenced by the skills, knowledge and experience possessed. This can demonstrate the level of competency possessed by a certain employee.

\subsection{Evaluation Skill}

Identifying the effectiveness of a training program and its' effects on the organization. Improvement in the quality and job output is influenced by the training receive by the employee. However, most of the time employers forget to evaluate the effect of trainings or courses provided to employees. Evaluation skill will help employers in identifying the relevant training and courses and in determining the effective follow-up training programmed for their employees. In an effective organization, employees who have received training or attended courses should be giving training in return or at least help to prepare training for their colleagues.

\subsection{Objective Preparation Skill}

Preparing a complete and specific statement related to job output to be achieved. The targeted or stated objectives should be achievable. They should consist of general objectives, specific objectives and if necessary should specify the trainings that are required to achieve each specific objective. The skill also involves preparing short-term objectives and long-term objectives. Skill in preparing objectives can make employees become focus 
on the task given by the employer.

\subsection{Research Skills}

Selecting, developing and using a suitable methodology such as statistics and data collection for formal inquiries or tasks given. Research skills can facilitate in elevating the fixed benchmark. It is a part of improvement in the existing system. Based on the research done, this skill will help employers to look at the increment in competency or the needs of competency. It also provides space to look for and to study the employee's trend in carrying out the tasks given.

\subsection{Training and Development Theory and Comprehension Technique}

Knowing the suitable theory and method used in the training and development of an organization and using the suitable and proper comprehension technique. Time and cost can be saved in carrying out additional training to employees who need to improve their present knowledge and skills. This technique is also a requirement in preparing relevant training and courses for the employees. Employers can prepare plans for training and staff development by considering the target achieved in the assessment year.

\section{Conclusion}

In general, knowledge, skills and behaviors are the main characteristics in competency evaluation as proposed by the competency model in Model for HRD Practice (McLagan, 1989). Competency can be divided into two includes individual competency that involves evaluation towards employees, specifically for the technical competency of technical human resources, and organizational competency for the development of technical human resources. Both forms of competency complement one another because the quality of an organization is evaluated based on employees' performance and the productivity of the organization.

Technical and Vocational Education should go hand in hand because it's more relevant to the market needs. Industries need human resources and workers who possess not only skills in technical and vocational fields but also have a quality and high job performance. Therefore, industries nowadays need competency evaluation for the human resources and workers in order for them to be more competitive and competent in the tasks given.

Technical and vocational education not only contributes to the growth of the nation's economy but also demonstrates worker characters in an organization. It has the sustainable development characters through the offering of programmed, curriculum development and implementation of teaching and learning that will produce human resources and workers who are competent, dynamic and more competitive.

\section{References}

Alseddiqi, M., Mishra, R., \& Pislaru, C. (2012). The new School-Based Learning (SBL) to Work-Based Learning (WBL) transition module: A practical implementation in the Technical and Vocational Education (TVE) system in Bahrain. Journal of Physics: Conference Series, 364. http://dx.doi.org/10.1088/1742-6596/ $364 / 1 / 012117$

Ashworth, P. D., \& Saxton, J. (1990). On 'competence'. Journal of Further and Higher Education, 14(2), 3-25. http://dx.doi.org/10.1080/0309877900140201

Ayonmike, C. S., Okwelle, P. C., \& Okeke, B. C. (2014). Competency based education and training in technical vocational education: Implication for sustainable national security and development. Journal of Education Policy and Entrepreneurial Research, 11(2), 290-300.

Bello, H., Shu'aibu, B., Saud, M. S., \& Buntat, Y. (2013). ICT skills for technical and vocational education graduates' employability. World Applied Sciences Journal, 23(2), 204-207.

Boyatzis, R. E. (1982). The Competent Manager: A Model for Effective Performance. New York, NY: John Wiley \& Sons.

Daugherty, J., Teng, Y. T., \& Cornachione, E. (2007). Rapid prototyping instructional design: Revisiting the ISD model. Presented at the International Research Conference in The Americas of the Academy of Human Resource Development, Indianapolis, IN. Retrieved from http://www.eric.ed.gov/PDFS/ED504673.pdf

Dubois, D. (1993). Competency based performance improvement: A strategy for organizational change. Amherst, MA: HRD Press Inc.

Hoffmann, T. (1999). The meaning of competency. Journal of European Industrial Training, 23(6), 275-286. http://dx.doi.org/10.1108/03090599910284650

Homer, M. (2001). Skills and competency management. Journal of Industrial and Commercial Training, 33(2), 


\section{8-136. http://dx.doi.org/10.1108/00197850110385624}

Jones, E., Voorhees, R., \& Paulson, K. (2002). Defining and assessing learning: Exploring competency-based initiatives. Washington, DC: Council of the National Postsecondary Education Cooperative

June, S., Kheng, Y. K., \& Mahmood, R. (2013). Determining the importance of competency and person-job fit for the job performance of service SMEs employees in Malaysia. Asian Social Science, 9(10), 114-123. http://dx.doi.org/10.5539/ass.v9n10p114

Kerka, S. (1998). Competency-based education and training myths and realities. ACVE Publication Archives. Retrieved from http://www.calpro-online.org/eric/textonly/docgen.asp?tbl=mr\&ID=65

Malaysia Government. (2001). The third outline perspective plan 2001-2010 of Malaysia. Malaysia: Government Press.

McLagan, P. A. (1989). Models for HRD practice. Training \& Development Journal, 43(9), 49-59.

McLagan, P. A. (1996). Great ideas revisited: Competency models, creating the future of HRD. Training and Development, 50(1), 60-65

Rothwell, W., \& Kazanas, H. (1992). Mastering the instructional design process: A systematic approach. San Francisco, CA: Jossey-Bass

Ruhland, S., Jurgens, C., \& Ballard, D. (2003). Tech prep's role in education reform: perception from state tech prep directors. Journal of Career and Technical Education, 20(1), 69-85.

Salleh, K. M. (2012). Human resource development practitioners' perspectives on competencies: An application of American Society for Training and Development (ASTD) Workplace Learning and Performance (WLP) competency model in Malaysia. Available from ProQuest Dissertation and Theses database. (UMI No. 3551639).

Salleh, K. M., Sulaiman, N. L., \& Gloeckner, G. W. (2015). The development of competency model perceived by Malaysian human resource practitioners' perspectives. Asian Social Science, 11(10), 175-185. http://dx.doi. org/10.5539/ass.v11n10p175

Sauber, M. H., McSurely, H. B., \& Tummala, V. M. R. (2008). Developing supply chain management program: A competency model. Quality Assurance in Education, 16(4), 375-391. http://dx.doi.org/10.1108/09684880 810906517

Serpell, A., \& Ferrada, X. (2007). A competency-based model for construction supervisors in developing countries. Personnel Review, 36(4), 585-602. http://dx.doi.org/10.1108/00483480710752812

Sulaiman, N. L. (2012). Incorporating critical thinking: Teaching strategies in Malaysian Technical and Vocational Education (TVE) programs. Available from ProQuest Dissertation and Theses database. (UMI No. 3551660).

\section{Copyrights}

Copyright for this article is retained by the author(s), with first publication rights granted to the journal.

This is an open-access article distributed under the terms and conditions of the Creative Commons Attribution license (http://creativecommons.org/licenses/by/3.0/). 